\title{
Discovery of a large population of Hygrolembidium isophyllum (Lepidoziaceae, Marchantiophyta) in the South Shetland Islands, Antarctica
}

\author{
Jair Putzke1 (D), Flávia Ramos Ferrari² (D) \& Carlos E.G.R. Schaefer ${ }^{3}$ (D) \\ 'Universidade Federal do Pampa, São Gabriel, Rio Grande do Sul, Brazil \\ 2Departamento de Biologia Vegetal, Universidade Federal de Viçosa, Viçosa, Minas Gerais, Brazil \\ ${ }^{3}$ Departamento de Solos, Universidade Federal de Viçosa, Viçosa, Minas Gerais, Brazil
}

\begin{abstract}
In February 2019, during fieldwork at Harmony Point, Nelson Island, South Shetland Islands, Antarctica, a large population of the rare liverwort Hygrolembidium isophyllum (Lepidoziaceae) was discovered. The occurrence of this rare species reinforces the need to preserve Antarctic Specially Protected Area 133.
\end{abstract}

\begin{abstract}
Keywords
Nelson Island; distribution; Antarctic Specially Protected Area; liverwort

\section{Correspondence}

Jair Putzke, Universidade Federal do Pampa, Av. Antonio Trilha, São Gabriel 97300-000, RS, Brazil. E-mail: jrputzkebr@yahoo.com
\end{abstract}

\section{Introduction}

Hygrolembidium isophyllum R.M. Schust is a representative of a small austral genus of the hepatic family Lepidoziaceae that is restricted in its distribution to the southern cool-temperate zone and polar regions; the genus occasionally penetrates into the tropics, where its species grow at high elevations in the mountains. It is an American Subantarctic species (Bednarek-Ochyra et al. 2000) occurring in southern South America, including the Falkland Islands, and on Subantarctic South Georgia (Hässel de Menéndez \& Rubies 2009). In addition, it extends to the northern maritime Antarctic, where it is known from some islands in the two peri-Antarctic archipelagoes, namely the South Orkney Islands (Coronation Island, Moe Island, Lynch Island and Signy Island) and the South Shetland Islands (Ardley Island and Nelson Island) (Bednarek-Ochyra et al. 2000). The alleged occurrence of this species on Cape Tuxen on Graham Coast on the West Antarctic Peninsula and on Powell Island in the South Orkney Islands, based on the personal communication of Dr R.I. Lewis Smith (Ochyra \& Váňa 1989a), proved to be erroneous (Bednarek-Ochyra et al. 2000).

Hygrolembidium isophyllum was found for the first time in the Antarctic in 1980 on King George Island, the largest of the South Shetland Islands, or rather, to be more precise, the species was found on Ardley Island, a small islet in Maxwell Bay, close to the south-west end of King George Island. This material was listed in Bryophyta
Antarctica exsiccata as No. 75 under the name H. ventrosum (Mitt.) Grolle (Ochyra 1984), but this misdescription was subsequently corrected (Ochyra et al. 1986; Ochyra \& Váňa 1989b). Later, the species was recorded on Nelson Island, another of the South Shetland Islands (BednarekOchyra et al. 2000). The material was collected by Vera Komárková, alas, without locality data, habitat and year of collection. It was apparently collected during the austral summers of $1982 / 83$ or $1983 / 84$, when she explored many sites in the maritime Antarctic with RV Hero (Komárková et al. 1985). It is very likely that she collected at Harmony Point, which appears to be the only site on Nelson Island where $H$. isophyllum is known to occur. To our knowledge, the species has not been found at Rip Point (Putzke et al. 1998), another large ice-free area on Nelson Island and therefore another potential location for $H$. isophyllum. The specimen of $H$. isophyllum from Nelson Island at the herbarium of the W. Szafer Institute of Botany, Polish Academy of Sciences (herbarium code KRAM), is fairly robust and this inferentially indicates that it was collected at a site where this liverwort could grow in abundance. The only such place on Nelson Island-except for Rip Point-is the Harmony Point area, so the present record in all likelihood represents a rediscovery of the species in this locality.

During fieldwork for soil and vegetation mapping carried out from January to February 2019, a large population of this species was found at Harmony Point, Nelson Island, and is described herein. 


\section{Material and methods}

The samples were collected on the plateau just north of the Argentine Refuge Gurruchaga in February 2019 at Harmony Point, Nelson Island, South Shetland Islands archipelago in the maritime Antarctica (Figs. 1-3). The area was completely measured and mapped to provide an accurate location of this population using drone images (Phantom 4 photographs) and the Agisoft Program to produce a map of the area. Microscopic slides were

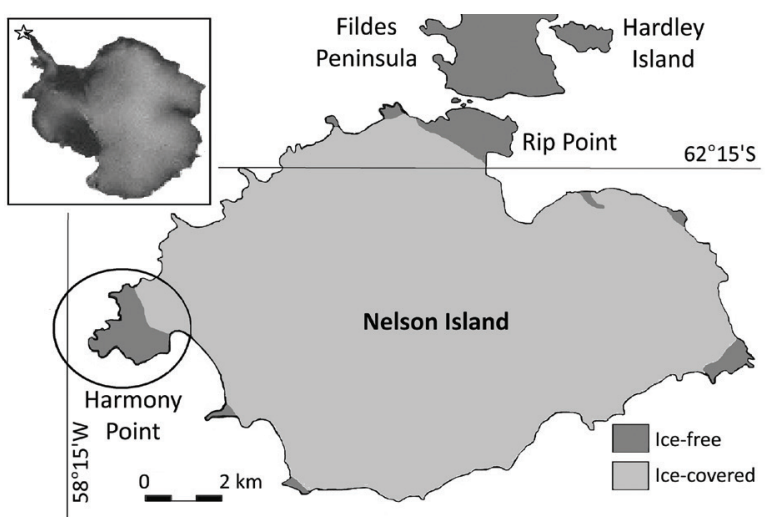

Fig. 1 Map showing the collection site at Harmony Point, Nelson Island, South Shetland Islands. The inset map of Antarctica indicates the location of this archipelago with a star.

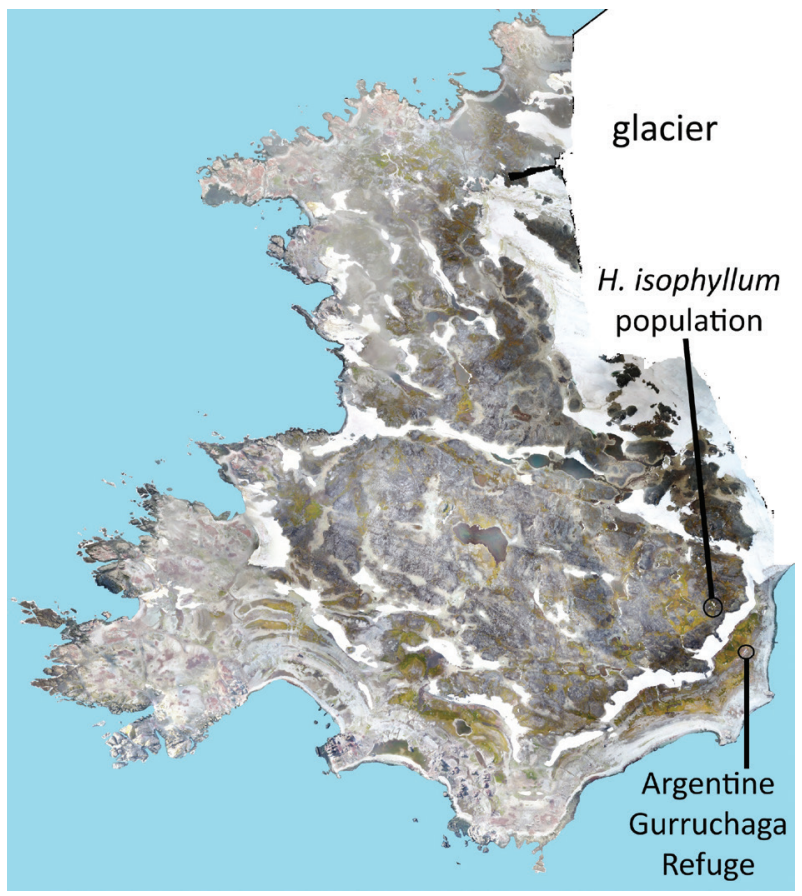

Fig. 2 Aerial composite photograph of Harmony Point, Nelson Island, showing the location of the Hygrolembidium isophyllum population. prepared as usual to study the anatomical structure of the liverwort and confirm identification using descriptions and illustrations presented in The liverwort flora of Antarctica (Bednarek-Ochyra et al. 2000). Microphotographs of its cells were taken in the laboratories of the Federal University of Pampa in São Gabriel, Rio Grande do Sul, Brazil.

\section{Results and discussion}

Hygrolembidium isophyllum R.M. Schust. Nova Hedwigia 15 (2-4): 467, pl. 56(8). (f.) 1-9. 1968. Description: Bednarek-Ochyra et al. (2000).

The species is easily identified by its julaceous stems, with strongly concave and imbricated leaves, with isophyllous to sub-isophyllous amphigastria. The leaves are unistratose to tristratose, with subquadrate laminal cells and slime papillae that occur at leaf margins (Fig. 5c). According to Bednarek-Ochyra et al. (2000), this combination of characters makes it an easily recognized species among the species of liverworts occurring in Antarctica.

Material examined: Antarctica, Nelson Island, Harmony Point, 62 $18^{\prime} 13.97^{\prime \prime} \mathrm{S}$ and 59 $11^{\prime} 48.06^{\prime \prime} \mathrm{W}, 64 \mathrm{~m}$ a.s.l. Plane area on a very wet habitat, growing with Polytrichastrum alpinum, Warnstorfia sarmentosa and Sanionia uncinata, 10 February 2019, collected and identified by J. Putzke, HCB (code for the herbarium of the Universidade de Santa Cruz do Sul) 30708.

The population was sterile, despite the large area occupied, as is typical in Antarctic material (Figs. 4, 5).

As noted by Bednarek-Ochyra et al. (2000), the intercalary branching was also noted in our collections, including some maintained in humid chambers, which developed lateral branching.

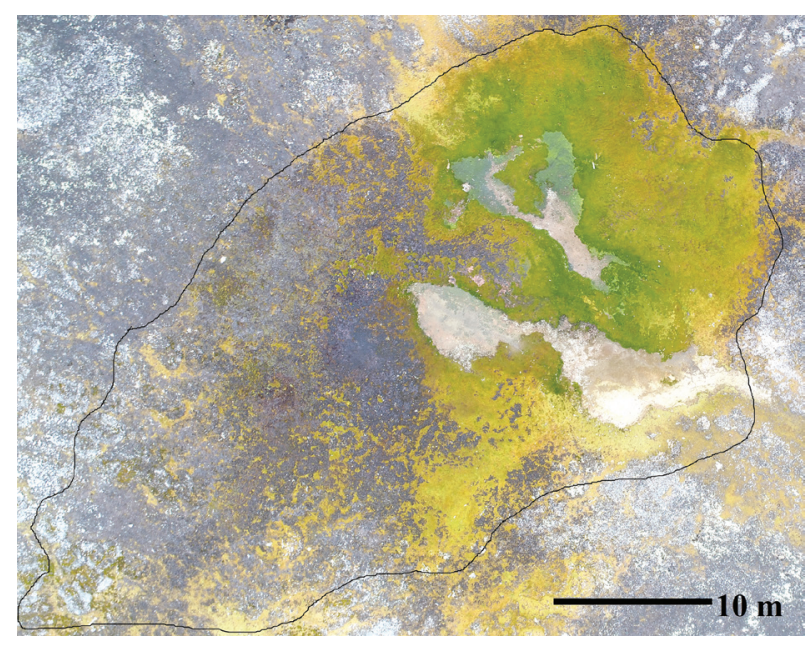

Fig. 3 Aerial photograph of Harmony Point, Nelson Island, with the location of the Hygrolembidium isophyllum population outlined. 


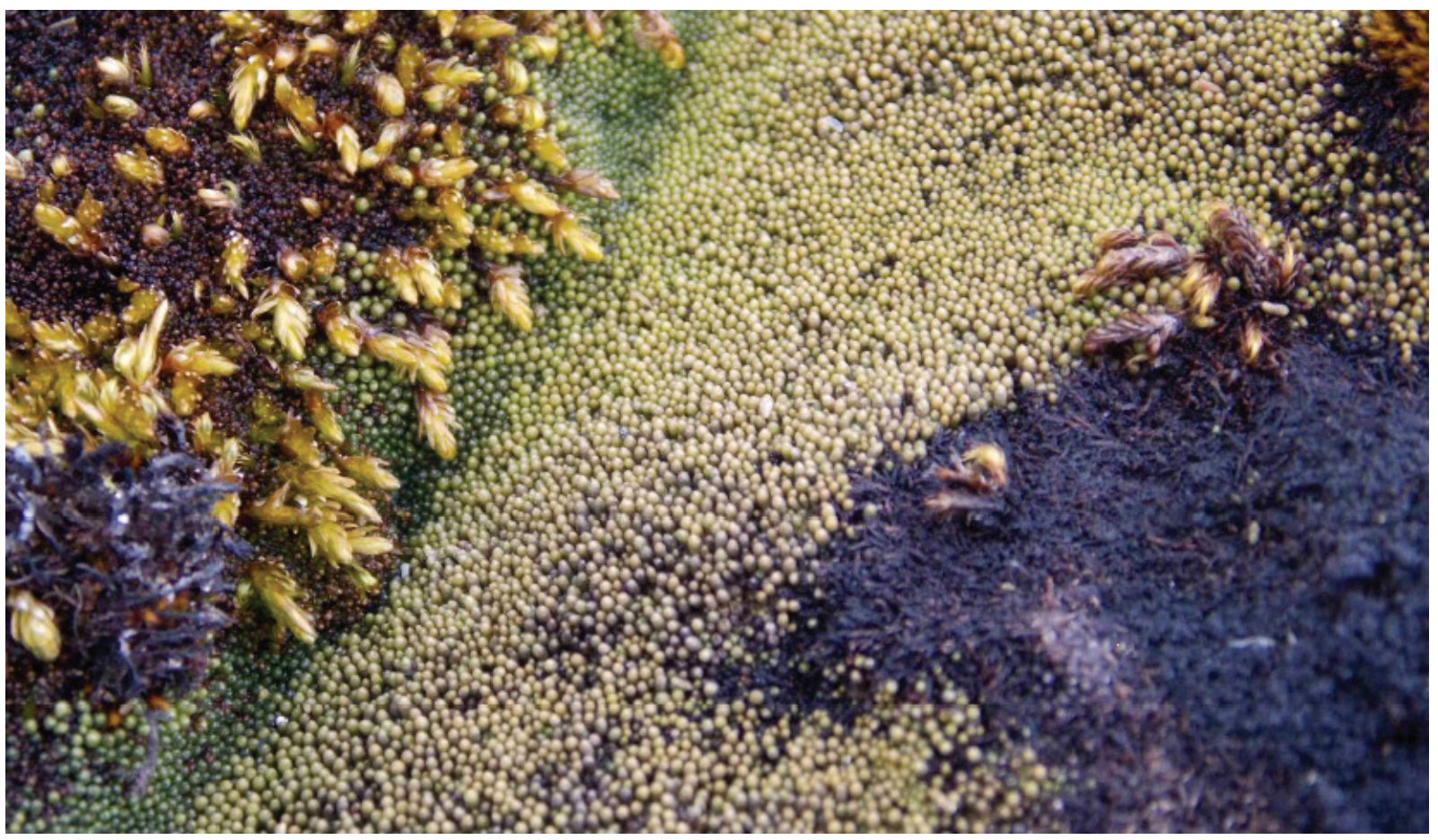

Fig. 4 Close up of the julaceous stems of the Hygrolembidium isophyllum population (centre).
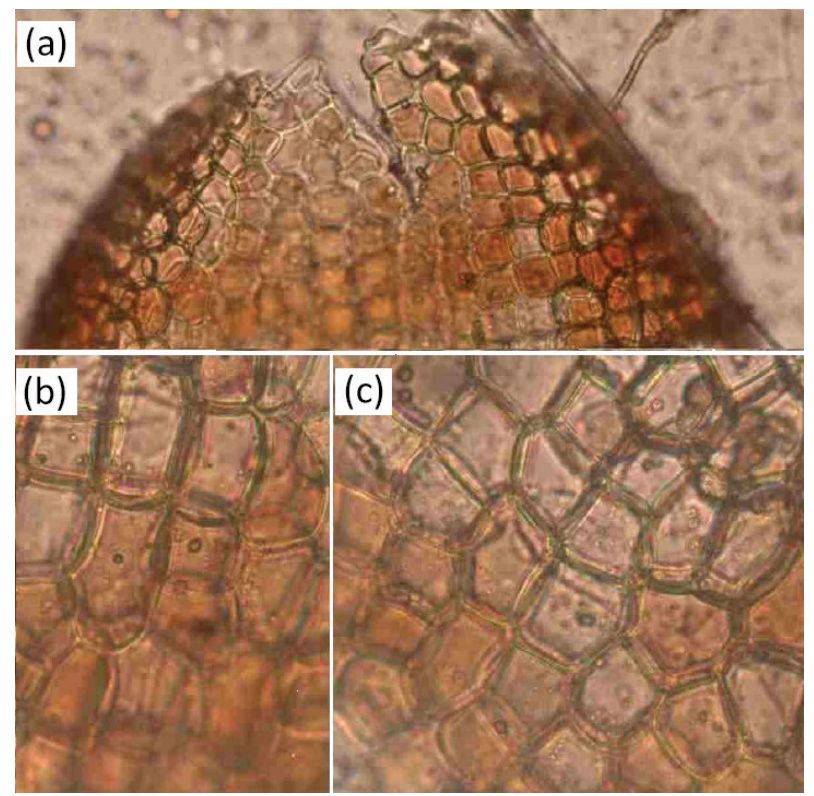

Fig. 5 Microscopic photographs of Hygrolembidium isophyllum: (a) apical leaf cells (200x); (b) and (c) median leaf cells (400x).

The population found at Harmony Point is located ca. $15 \mathrm{~km}$ south-west of Ardley Island, where it was reported occurring as Hygrolembidium ventrosum by Ochyra (1984), Ochyra et al. (1986) and Ochyra \& Váňa (1989b).
The liverwort covers an area of $50 \times 30 \mathrm{~m}(64 \mathrm{~m}$ a.s.l.) in a habitat that becomes very wet from snowmelt, forming a light green coverage, mixed with Polytrichastrum alpinum (Hedwig) G.L. Smith, Warnstorfia sarmentosa (Wahlenb.) Hedenäs and Sanionia uncinata (Hedw.) Loeske. At some places the black form of Cephalozia varians (Gottsche) Steph. is also found.

The population is ca. $200 \mathrm{~m}$ north of the Argentine Gurruchaga Refuge and both are within Antarctic Specially Protected Area 133. Our findings reinforce the need to protect this area, since this species is very rare in Antarctica. At the small southern giant petrel (Macronectes giganteus) colony, roughly $90 \mathrm{~m}$ away, we counted that only six nests were used; its influence on the community is probably very low. A small lake $(12 \times 6 \mathrm{~m})$ and the snow deposits that supply it with meltwater, in addition to the low incidence of wind, are abiotic factors that could be influencing the occurrence of the species in the area.

The occurrence of this rare liverwort in close proximity with old stations and refuges suggests a possible recent invasion of the South Shetland Islands due to rapid regional warming.

\section{Disclosure statement}

The authors report no potential conflict of interest. 


\section{Acknowledgements}

This work is a contribution of the Terrantar Project-Permafrost, Cryosoils and Terrestrial Ecosystems and Climatic Change Studies in Antarctica-of Brazil's National Scientific and Technological Institute of the Cryosphere.

\section{Funding}

The authors acknowledge the Coordenação de Aperfeiçoamento de Pessoal de Nível Superior for granting scholarship and the Conselho Nacional de Desenvolvimento Científico e Tecnológico for financial support of this project (project no. 556794/2009-5).

\section{References}

Bednarek-Ochyra H., Váňa J., Ochyra R. \& Lewis Smith R.I. 2000. The liverwort flora of Antarctica. Kraków, Poland: Institute of Botany, Polish Academy of Sciences.

Hässel de Menéndez G. \& Rubies M.F. 2009. Catalogue of Marchantiophyta and Anthocerotophyta of southern South America: Chile, Argentina and Uruguay, including Easter Is.
(Pascua I.), Malvinas Is. (Falkland Is.), South Georgia Is., and the Subantarctic South Shetland Is., South Sandwich Is., and South Orkney Is. Nova Hedwigia Beiheft 134. Stuttgart, Germany: J. Cramer.

Komárková V., Poncet S. \& Poncet J. 1985. Two native Antarctic vascular plants, Deschampsia antarctica and Colobanthus quitensis: a new southernmost locality and other localities in the Antarctic Peninsula area. Arctic and Alpine Research 17, 401-416, doi: 10.1080/00040851.1985.12004047.

Ochyra R. 1984. Bryophyta Antarctica Exsiccata. Nos. 1-200. Edmonton, Canada: University of Alberta.

Ochyra R. \& Váňa J. 1989a. The hepatics reported from the Antarctic and an outline of their phytogeography. Polish Polar Research 10, 211-229.

Ochyra R. \& Váňa J. 1989b. The hepatics of King George Island, South Shetland Island, Antarctica, with particular reference to the Admiralty Bay region. Polish Polar Research $10,183-210$.

Ochyra R., Vitt D.H. \& Horton D.G. 1986. An annotated guide to Bryophyta Antarctica Exsiccata. Cryptogamie, Bryologie-Lichénologie 7, 53-62.

Putzke J., Pereira A.B. \& Putzke M.T.L. 1998. Moss communities of Rip Point in northern Nelson Island, South Shetland Islands, Antarctica. Pesquisa Antártica Brasileira 3, 103-115. 